\title{
Species-Specific Detection of the Maize Pathogens Sporisorium reiliana and Ustilago maydis by Dot Blot Hybridization and PCR-Based Assays
}

\author{
M. L. Xu, Department of Agronomy, Yangzhou University, 225009 Yangzhou, PR China; A. E. Melchinger, Insti- \\ tute of Plant Breeding, Seed Science, and Population Genetics, University of Hohenheim, D-70593 Stuttgart, Ger- \\ many; T. Lübberstedt, Institute of Plant Breeding, Seed Science, and Population Genetics, University of Hohen- \\ heim, D-70593 Stuttgart, Germany
}

\begin{abstract}
Xu, M. L., Melchinger, A. E., and Lübberstedt, T. 1999. Species-specific detection of the maize pathogens Sporisorium reiliana and Ustilago maydis by dot blot hybridization and PCR-based assays. Plant Dis. 83:390-395.

Head smut of maize, caused by Sporisorium reiliana, may substantially reduce grain yield. The objective of the present study was to develop a highly specific and sensitive DNA-based assay for detection of $S$. reiliana and its differentiation from Ustilago maydis, a maize fungus inducing the symptomatically similar common smut disease. Plasmid libraries of S. reiliana and U. maydis were constructed using a shotgun cloning procedure. Clones containing strongly hybridizing species-specific DNA were selected by screening libraries with their own labeled genomic DNA, followed by cross-hybridization with genomic DNA of maize and other maize-pathogenic fungi. The selected clones were used to generate subclones with short insert fragments to facilitate PCR amplification for labeling and primer design for a PCR assay. Using Dig-dUTP labeled inserts, detection of less than $0.16 \mathrm{ng}$ of fungal DNA was possible by dot blot hybridization. Sequences of insert fragments were determined to design primer pairs for a PCR-based assay. Primer pairs SR1 and SR3 are species-specific for S. reiliana, and UM11 is species-specific for $U$. maydis. The PCR-based assays can detect fungal DNA of less than $1.6 \mathrm{pg}$ using SR1 and SR3, and 8 pg using UM11, irrespective of the presence of maize DNA. Use of SR1 and SR3 allowed detection of $S$. reiliana in the extracts of pith, node, and shank from $S$. reilianainfected plants, but not in leaves. Thus, both the dot blot hybridization and the PCR-based assays provide a highly sensitive and reliable tool for detection and differentiation of corn smut caused either by $S$. reiliana or by $U$. maydis.
\end{abstract}

Sporisorium reiliana (Kühn) Langdon \& Fullerton (syn. Sphacelotheca reiliana (Kühn) Clint.) is the causal agent of head smut in maize $(14,15)$, a disease widespread in North America, Asia, and southern Europe. Recently, head smut became a potential threat to maize production in Germany (5). The fungus invades plants during emergence or at the seedling stage through soilborne teliospores and grows systemically with the meristem. Infection becomes visible at a late stage of plant development, when tassels and ears are partially or totally replaced by sori filled with teliospores.

Another maize pathogen, Ustilago maydis, induces localized tumor formation on leaves, stem, tassel, and ear, and causes stunting (2). The disease is known as

Corresponding author: T. Lübberstedt
E-mail: luebbit@uni-hohenheim.de

Accepted for publication 22 December 1998.

Publication no. D-1999-0212-01R

(c) 1999 The American Phytopathological Society common smut, and infected ears show symptoms very similar to those caused by $S$. reiliana. Smut caused by both fungi can lead to substantial losses in grain yield within the infected plants $(3,5,28)$. S. reiliana can be controlled chemically, but not $U$. maydis. However, for economic and ecological reasons, cultivation of resistant varieties is the preferred control strategy for both diseases. Breeding for resistance against both fungi is promising in view of the large genetic variation present in maize germ plasm and the preponderance of additive gene action underlying these traits $(1,3)$. At present, diagnosis of both pathogens is based on the presence or absence of galls, which usually become visible after flowering. Efficiency of resistance breeding could be improved substantially by diagnostic tools that allow reliable evaluation for resistance to both fungi before flowering.

Recently, highly specific and sensitive molecular hybridization and polymerase chain reaction (PCR) assays were introduced for the detection and diagnosis of plant diseases. These methods were developed by exploiting abundant DNA se- quences present in several copies per single cell, including (i) repetitive DNA sequences $(17,18)$, (ii) rDNA and its internal transcribed spacer (ITS) regions $(10,11$, 12,25), and (iii) extrachromosomal DNA sequences $(13,16,29)$ or single-copy sequences $(4,8,10,19,21)$. Hitherto, molecular techniques have not been used for diagnosis of maize plants infected by $S$. reiliana and $U$. maydis, even though the latter has been well characterized at the molecular level for several characters, including pathogenicity (2). The objective of our work was to develop (i) molecular assays for sensitive detection of the systemically infecting maize pathogen $S$. reiliana and (ii) a tool for unambiguous differentiation of galls formed after infection by either S. reiliana or U. maydis.

\section{MATERIALS AND METHODS}

Sources of fungal strains and extraction of DNA. S. reiliana isolates SI1, SI2, SI3, SI4, and SI5 were collected from different maize genotypes in fields near Chantonnay (Western France), and SI7, SI9, and SI10 were collected near Colmar (Rhine Valley) in 1996. U. maydis isolates UI1, UI2, UI4, UI6, UI7, UI8, UI9, and UI10 were collected from fields at Stuttgart-Hohenheim (Germany) and Cadenazzo (Switzerland) in 1993 and 1994; isolates from the ATCC catalog, 22899, 22900, 22901, 22903, 22904, and 22905, originated in the United States (22). Teliospores of $S$. reiliana and $U$. maydis were used to develop single-spore isolates. About $10 \mathrm{mg}$ of teliospores was suspended in $500 \mu \mathrm{l}$ of sterile distilled water $\left(\mathrm{dH}_{2} \mathrm{O}\right)$ and precipitated by centrifugation at 9,000 $\times g$ for $30 \mathrm{~s}$. The supernatant was decanted, and washing was repeated three times. Purified teliospores were sterilized with ampicillin $(4 \mathrm{mg} / \mathrm{ml})$ at room temperature (RT) for $1 \mathrm{~h}$. After two additional washings with $\mathrm{dH}_{2} \mathrm{O}$, teliospores were resuspended in $400 \mu \mathrm{l}$ of $\mathrm{dH}_{2} \mathrm{O}$ and diluted 1:10, 1:100, $1: 1,000$, and $1: 10,000 ; 200 \mu \mathrm{l}$ of each diluted teliospore suspension was streaked on YEPS (1\% yeast extract, $2 \%$ peptone, $2 \%$ sucrose, $2 \%$ agar) medium containing $100 \mu \mathrm{g}$ of ampicillin per $\mathrm{ml}$ and incubated at $30^{\circ} \mathrm{C}$ for 3 to 4 days to develop fungal 
colonies. Single colonies were streaked on plates two additional times to obtain single-spore isolates.

Single-spore isolates were grown at $30^{\circ} \mathrm{C}$ for 2 to 3 days in $10 \mathrm{ml}$ of liquid YEPS medium with constant shaking. Fungal cells were harvested by centrifugation at $1,500 \times g$ for $15 \mathrm{~min}$, washed once with $1 \mathrm{ml}$ of $\mathrm{dH}_{2} \mathrm{O}$ by centrifugation, and mixed with about $0.4 \mathrm{~g}$ of glass beads ( 0.25 to $0.56 \mathrm{~mm}$ diameter) together with 4 $\mathrm{ml}$ of CTAB (cetyltrimethylammonium bromide hydroxide) extraction buffer $(0.1$ M Tris-HCl, pH 7.5, 0.7 M NaCl, 10 mM EDTA, 1\% CTAB). The mixture was vortexed for 3 min to damage cell walls and kept at $65^{\circ} \mathrm{C}$ for $2 \mathrm{~h}$ with gentle rocking. The subsequent DNA extraction was done as described by Hoisington et al. (7) with one additional purification step using chloroform/isoamyl alcohol to obtain highquality DNA. DNA concentration was determined by comparing with standard molecular markers on agarose gel.

Construction of plasmid libraries of $S$. reiliana and $\boldsymbol{U}$. maydis. Genomic DNA of $S$. reiliana isolate SI1 and $U$. maydis isolate UI1 was digested with EcoRV at $37^{\circ} \mathrm{C}$ for $2 \mathrm{~h}$ and ligated into SmaI-digested plasmid pBluescript (Stratagene $\mathrm{GmbH}$, Heidelberg, Germany) in the presence of SmaI to prevent self-ligation of plasmid DNA. Ligation products were transformed into competent cells of Escherichia coli strain $\mathrm{DH} 5 \alpha$ by using a $\mathrm{CaCl}_{2}$ precipitation method (24). White colonies bearing recombinant plasmids were obtained on LB ( $1 \%$ peptone, $0.5 \%$ yeast extract, $1 \% \mathrm{NaCl}$, $2.0 \%$ agar) medium containing $50 \mu \mathrm{g}$ of ampicillin per $\mathrm{ml}$ (LB amp medium), 5bromo-4-chloro-3-indolyl- $\beta$-D-galactopyranoside, and isopropyl- $\beta$-D-thiogalactopyranatranoside, replated on a fresh LB amp medium, and maintained at $4^{\circ} \mathrm{C}$ for further analysis.

Selection of colonies containing species-specific abundant sequences. Colonies containing species-specific abundant sequences (repetitive and mitochondrial DNA) were screened by colony hybridization using their own genomic DNA labeled with Dig-dUTP, followed by cross-hy- bridization, in which colonies of $S$. reiliana were cross-hybridized to $U$. maydis DNA probes and vice versa. Only those colonies that showed strong signals in colony hybridization but no or very weak signals in cross-hybridization were selected for further analysis, assuming they contain species-specific abundant sequences.

Subcloning. Recombinant plasmids from selected colonies were digested with different restriction enzymes (SacI, HindIII, ApaI, BamHI, and EcoRI), which have single recognition sites in the polylinker region of plasmid pBluescript. If one or more restriction sites for a given enzyme were present in an insert fragment, a part of it would be deleted after digestion. The subsequent self-ligated products were used to transform competent cells of E. coli strain DH5 $\alpha$ and plated on LB amp medium to develop new recombinant plasmids with smaller insert fragments.

Colony, dot blot, and Southern hybridization. For colony blotting, white colonies containing recombinant plasmids were replated on nylon filters (Schleicher \& Schuell, Dassel, Germany) lying on LB amp medium plates and subsequently cultured at $37^{\circ} \mathrm{C}$ for 8 to $10 \mathrm{~h}$. The freshly grown colonies of about $1 \mathrm{~mm}$ diameter were lysed with $0.4 \mathrm{~N} \mathrm{NaOH}$ and $10 \%$ SDS, neutralized with $0.5 \mathrm{M}$ Tris- $\mathrm{HCl}$ and $1.5 \mathrm{M} \mathrm{NaCl}(\mathrm{pH} \mathrm{7.4)}$, and fixed on nylon filters by incubating at $80^{\circ} \mathrm{C}$ for $2 \mathrm{~h}$.

For evaluation of the species-specificity of probes in a dot blot assay, genomic DNA of $S$. reiliana, $U$. maydis, and other maize pathogens (Fusarium graminearum, Setosphaeria turcica), as well as maize DNA, were denatured with equal volumes of $1 \mathrm{~N} \mathrm{NaOH}$. Subsequently, $2 \mu \mathrm{l}$ of each DNA (about $100 \mathrm{ng}$ ) was dot-blotted on nylon filters. To check the sensitivity of probes, concentration of fungal DNA was adjusted to $100,20,4,0.8,0.16$, and 0.032 $\mathrm{ng} / \mu \mathrm{l}$ by dilution and mixed with an equal volume of maize genomic DNA (100 $\mathrm{ng} / \mu \mathrm{l})$. Denaturation and dot blot were done as described above.

For Southern blotting, genomic DNA of $S$. reiliana and $U$. maydis was digested by BamHI, EcoRI, EcoRV, and HindIII, elec- trophoresed in $1 \%$ agarose gels, and transferred onto nylon membranes by vacuum blotting (Pharmacia LKB, Germany) according to the manufacturer's protocol.

Fungal genomic DNA was labeled with Digoxigenin-11-dUTP (Dig-dUTP, Boehringer, Mannheim, Germany) by using a random primed DNA labeling kit; DigdUTP labeled inserts of subclones were prepared by PCR amplification with M13 sequencing primers according to standard protocols (7). Prehybridization, hybridization, and detection with chemiluminescent substrate CSPD (Boehringer) were performed as recommended by Hoisington et al. (7). The membranes were exposed to Fuji X-ray film (Fuji Photofilm Europe $\mathrm{GmbH}$, Germany) for $3 \mathrm{~h}$ at RT.

DNA sequence analysis. Recombinant plasmids were prepared by using a QIAGEN plasmid mini preparation kit (QIAGEN GmbH, Germany) as recommended by the manufacturer. Inserts were partially sequenced from both ends by using the AutoRead sequencing kit (Amersham Pharmacia Biotech, Freiburg, Germany) with fluorescent universal and reverse primers on an ALF automated DNA sequencer (Amersham). The sequences were compared with the entire set of sequences available in GenBank Sequence Database by using the FASTA program.

Primer design and PCR assay. Primers for PCR assays were designed based on the insert terminal sequences with the aid of computer program Primer-Find 3.0 (K. Ellinger, Erlangen, Germany) and synthesized by Amersham Pharmacia Biotech.

Two sets of template DNA were prepared by mixing fungal DNA of different concentrations $(1,000,200,40,8,1.6,0.32$, and $0.064 \mathrm{pg} / \mu \mathrm{l})$ with equal volumes of either $\mathrm{dH}_{2} \mathrm{O}$ or maize DNA (100 $\left.\mathrm{ng} / \mu \mathrm{l}\right)$, respectively. PCR amplification was carried out in a final volume of $30 \mu \mathrm{l}$ of 10 $\mathrm{mM}$ Tris- $\mathrm{HCl}$ (pH 9.0), $50 \mathrm{mM} \mathrm{KCl}, 2.0$ $\mathrm{mM} \mathrm{MgCl}_{2}, 50 \mu \mathrm{M}$ each of dATP, dTTP, dGTP, and dCTP, $0.2 \mu \mathrm{M}$ of each primer, 2 $\mu \mathrm{l}$ of template DNA, and 0.5 units of Taq polymerase (Amersham). The reaction was performed in a PTC-100 thermocycler (MJ

Table 1. Clones, size of insert fragments, and degrees of cross-reaction from various types of abundant DNA sequences of Sporisorium reiliana and Ustilago maydis

\begin{tabular}{|c|c|c|c|c|c|c|c|c|}
\hline \multirow[b]{2}{*}{ Species } & \multirow{2}{*}{$\begin{array}{c}\text { Type of } \\
\text { abundant } \\
\text { sequence }\end{array}$} & \multirow[b]{2}{*}{ Name of clone } & \multirow{2}{*}{$\begin{array}{l}\text { Insert size } \\
\quad \text { (kb) }\end{array}$} & \multicolumn{5}{|c|}{ Hybridization with DNA ${ }^{a}$} \\
\hline & & & & SR & $\mathbf{U M}$ & FG & ST & $\mathbf{M}$ \\
\hline \multirow[t]{4}{*}{ S. reiliana } & 1 & $\mathrm{pS} 1, \mathrm{pS} 2, \mathrm{pS} 5, \mathrm{pS} 7, \mathrm{pS} 8$ & 6.0 & + & $\mathrm{w}$ & - & - & - \\
\hline & 2 & $\mathrm{pS} 3, \mathrm{pS} 4$ & 4.2 & + & - & - & - & - \\
\hline & 3 & pS9 & 2.8 & + & + & _- & _- & _- \\
\hline & 4 & $\mathrm{pS} 10$ & 3.8 & + & + & - & - & - \\
\hline \multirow[t]{5}{*}{ U. maydis } & 1 & pU1, pU5 & 1.9 & w & + & - & - & - \\
\hline & 2 & pU2, pU6, pU9 & 2.0 & - & + & - & - & - \\
\hline & 3 & pU4 & 5.6 & - & + & - & - & - \\
\hline & 4 & pU7 & 2.8 & w & + & _- & - & - \\
\hline & 5 & pU8 & 5.8 & w & + & - & - & - \\
\hline
\end{tabular}

\footnotetext{
${ }^{a}$ Hybridization data came from both Southern and dot blot hybridization for species $S$. reiliana (SR), U. maydis (UM), Fusarium graminearum (FG),
} Setosphaeria turcica (ST), and maize (M). +, strong signal; w, weak signal; -, no signal. 
Research, Inc.) using the following parameters: 1 cycle of $4 \mathrm{~min}$ at $94^{\circ} \mathrm{C}, 1 \mathrm{~min}$ at $56^{\circ} \mathrm{C}$, and $2 \mathrm{~min}$ at $72^{\circ} \mathrm{C}$, followed by 36 cycles of $1 \mathrm{~min}$ at $94^{\circ} \mathrm{C}, 1 \mathrm{~min}$ at $56^{\circ} \mathrm{C}$, and $2 \mathrm{~min}$ at $72^{\circ} \mathrm{C}$. The final step was a 10 min chain extension at $72^{\circ} \mathrm{C}$. The PCR products were analyzed by electrophoresis on $1 \%$ agarose gels.

PCR-based diagnosis. Leaves, nodes, piths, and shanks from $S$. reiliana-infected and -noninfected maize plants were harvested from a field near Chantonnay and at Stuttgart-Hohenheim in September 1997. Total DNA was extracted by using the CTAB extraction method (7). About 100 ng of DNA samples was added in the PCR reaction using a protocol as described above.

\section{RESULTS}

Species-specific abundant sequences in $S$. reiliana and $U$. maydis. From two times 280 colonies, containing recombinant plasmids for either $S$. reiliana or $U$. maydis, $21 \mathrm{~S}$. reiliana and $20 \mathrm{U}$. maydis clones were identified that showed strong signals in colony hybridization with their own labeled genomic DNA, but no or weak signals with the other labeled genomic DNA. Out of these clones, 10 were randomly selected for each species for further analysis. Based on their insert sizes and Southern and dot blot hybridization patterns, four types of abundant sequences of $S$. reiliana and five types of $U$. maydis were identified (Table 1). For $S$. reiliana, type 2 abundant sequence did not cross-hybridize with any other fungal DNA; type 1 showed weak cross-reaction with $U$. maydis; and types 3 and 4 showed

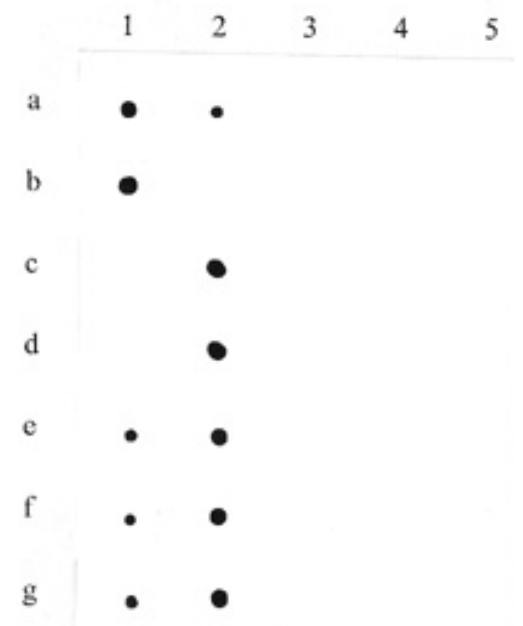

Fig. 1. Dot blot hybridization using cloned DNA probes of Sporisorium reiliana and Ustilago maydis to $100 \mathrm{ng}$ of total genomic DNA of $S$. reiliana (1), $U$. maydis (2), Fusarium graminearum (3), Setosphaeria turcica (4), and maize (5). Probes used were pSS11 (row a), pSS34 (row b), pSU22 (row c), pSU41 (row d), pSU11 (row e), pSU71 (row f), and pSU81 (row g). Membrane was exposed to X-ray film for $3 \mathrm{~h}$ at room temperature. cross-reactions with $U$. maydis. For $U$. maydis, types 2 and 3 did not show any cross-reactions; whereas types 1,4 , and 5 weakly cross-hybridized with $S$. reiliana. One clone from each of seven types showing no or weak cross-reactions was selected for further analysis: $\mathrm{pS} 1$ and $\mathrm{pS} 3$ for $S$. reiliana, and pU1, pU2, pU4, pU7, and $\mathrm{pU} 8$ for $U$. maydis.

Subcloning and characterization of fragments. Insert sizes of the seven selected clones ranged from 1.9 to $6.0 \mathrm{~kb}$ (Table 1). Most inserts were too long to be used in both primer design for PCR assay and efficient PCR-based labeling. By using restriction enzymes HindIII for $\mathrm{pS} 1$ and EcoRI for the other six plasmids, seven subclones designated pSS11, pSS34, pSU11, pSU22, pSU41, pSU71, and pSU81 were obtained with smaller insert fragments ranging from 0.6 to $1.3 \mathrm{~kb}$. In both Southern hybridization with DNA of S. reiliana, U. maydis, and maize, and dot blot hybridization with DNA of $S$. reiliana, $U$. maydis, F. graminearum, S. turcica, and maize, the same banding patterns were observed for each Dig-dUTP labeled subclone probe compared with the respective original one. As shown in dot blot hybridization (Fig. 1), pSS34, pSU22, and pSU41 were species-specific, while pSS11, pSU11, pSU71, and pSU81 showed weak cross-reactions with $U$. maydis (pSS11) or S. reiliana (pSU11, pSU71, and pSU81). However, for all probes tested, no crossreaction was found with DNA of maize or $F$. graminearum and $S$. turcica.

In Southern analyses of DNA from all eight $S$. reiliana isolates digested with the four restriction enzymes BamHI, EcoRI, EcoRV, and HindIII, identical banding patterns were observed among these isolates using $S$. reiliana probes pSS11 or pSS34. In parallel analyses of all $14 U$. maydis isolates digested with the same four restriction enzymes, probes pSU22 and

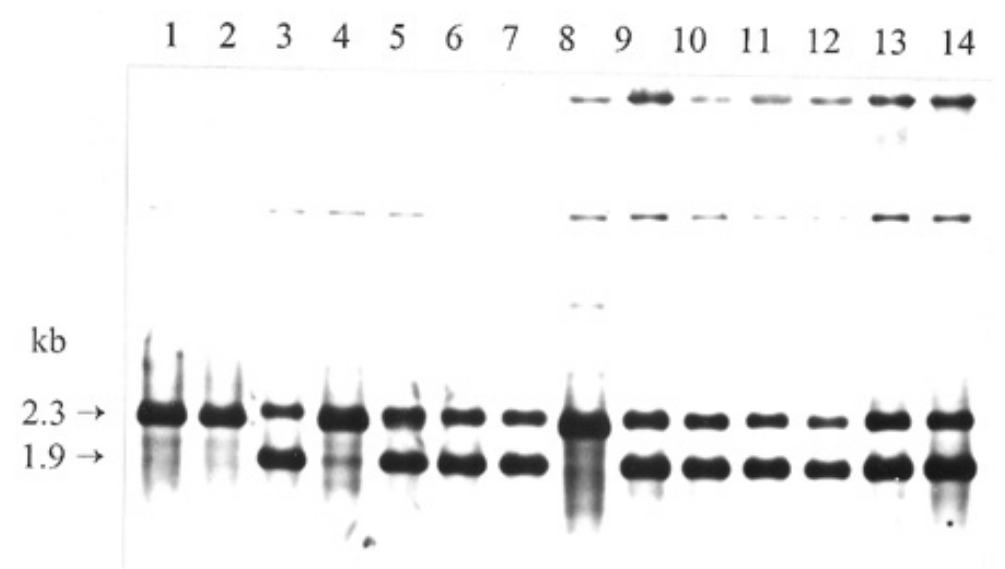

Fig. 2. Southern blot of EcoRI-digested DNA extracted from 14 Ustilago maydis isolates hybridized with the Dig-dUTP labeled insert fragment of pSU11. Lanes 1 to 14 refer to $U$. maydis isolates UI1 (1), UI2 (2), UI3 (3), UI4 (4), UI5 (5), UI6 (6), UI7 (7), UI8 (8), 22899 (9), 22900 (10), 22901 (11), 22903 (12), 22904 (13), and 22905 (14). Membrane was exposed to X-ray film for $3 \mathrm{~h}$ at room temperature.

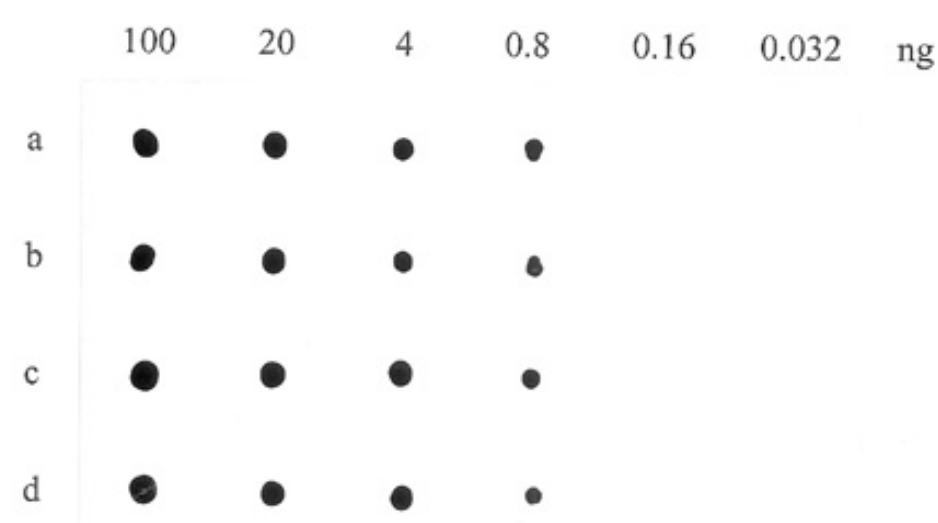

Fig. 3. Determination of sensitivity of cloned DNA probes from Sporisorium reiliana and Ustilago maydis by dot blot hybridization. DNA of $S$. reiliana (rows a and b) and $U$. maydis ( rows c and d) spiked with maize DNA (100 ng for each dot) was denatured with $1 \mathrm{~N} \mathrm{NaOH}$, dot blotted on nylon membrane, and hybridized to Dig-dUTP labeled DNA probes of insert fragments from pSS11 (row a), pSS34 (row b), pSU11 (row c), and pSU71 (row d). Numbers at the top represent the amount of dotted fungal DNA. 
pSU41 hybridized strongly to isolates UI1, UI2, UI6, and UI10, faintly to UI7, but not to the nine other isolates. Probes pSU11, pSU71, and pSU81 hybridized to all 14 isolates but resulted in different banding patterns under each of four restriction enzymes tested: isolates UI1, UI2, UI6, and mon; isolates UI4, UI8, UI9, 22899, had the second banding pattern in common; isolate UI7 had the second banding UI10 had the first banding pattern in com22900, 22901, 22903, 22904, and 22905

pattern by using probes pSU11 and pSU81 under restriction enzyme EcoRI (Fig. 2), but it showed additional weak bands when using probe pSU71 or under the other three restriction enzymes BamHI, EcoRV, and HindIII. In addition, probe pSU11 produced the same banding patterns as probe pSU81 among all $14 U$. maydis isolates.

Only probes capable of hybridizing to all isolates for a given species are suitable for developing species-specific probes and PCR primers. As a consequence, subclones

Table 2. Primer pairs designed to amplify abundant fungal DNA sequences of Sporisorium reiliana and Ustilago maydis

\begin{tabular}{|c|c|c|c|}
\hline $\begin{array}{l}\text { Name of } \\
\text { primer pair }\end{array}$ & Primer sequence & Target species & $\begin{array}{c}\text { Expected } \\
\text { fragment length }\end{array}$ \\
\hline SR1 & $\begin{array}{l}5^{\prime} \text { - CAGGTTATGTATGGGCCG - 3' } \\
5^{\prime} \text { - TTGAGCGATGACCATTCC - 3' }\end{array}$ & S. reiliana & $0.96 \mathrm{~kb}$ \\
\hline SR3 & $\begin{array}{l}5^{\prime}-\text { GCAGCCTCAGCATTACTC - 3' } \\
5^{\prime} \text { - ATACACCTGTGACGGCTG - 3' }\end{array}$ & S. reiliana & $0.68 \mathrm{~kb}$ \\
\hline UM1 & $\begin{array}{l}5^{\prime} \text { - AAGATAGTAGGGCTCGAACC - } 3^{\prime} \\
5^{\prime} \text { - CAATGTAATTCGTTCCGGCC - } 3^{\prime}\end{array}$ & U. maydis & $\ldots$ \\
\hline UM7 & $\begin{array}{l}5^{\prime}-\text { CATATGGACAATACTGCTCG - 3' } \\
5^{\prime} \text { - CTGCAGTTTCTCCATACCCG - 3' }\end{array}$ & U. maydis & $\ldots$ \\
\hline UM11 & $\begin{array}{l}5^{\prime}-\text { GAACCTTTCTGGCCTCCTTT - } 3^{\prime} \\
5^{\prime} \text { - CCTTGGTTTCCGTTCCGTAC - } 3\end{array}$ & U. maydis & $0.90 \mathrm{~kb}$ \\
\hline
\end{tabular}

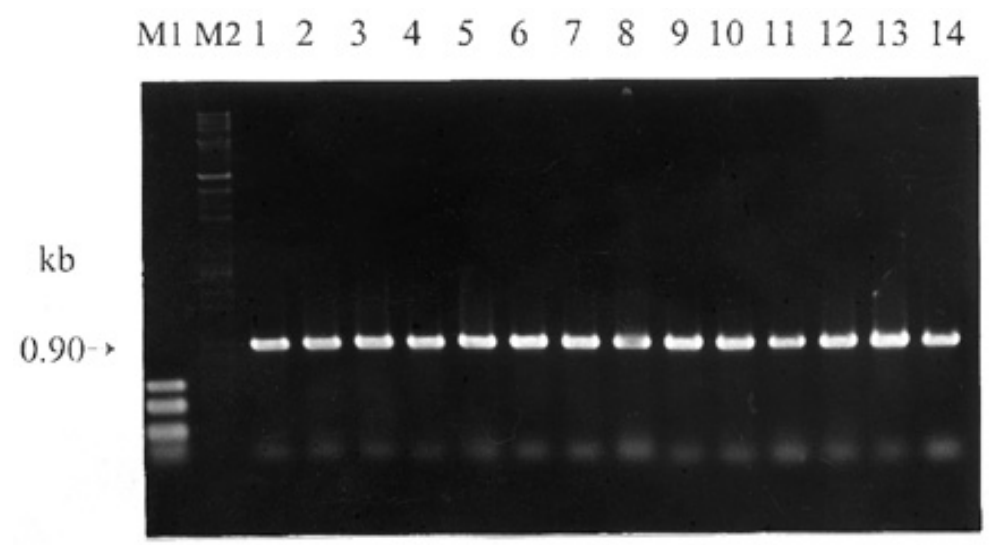

Fig. 4. Polymerase chain reaction (PCR) amplification using total DNA extracted from 14 Ustilago maydis isolates-UI1 (1), UI2 (2), UI3 (3), UI4 (4), UI5 (5), UI6 (6), UI7 (7), UI8 (8), 22899 (9), 22900 (10), 22901 (11), 22903 (12), 22904 (13), and 22905 (14) —as templates for primer pair UM11. PCR products were electrophoresed on a $1 \%$ agarose gel. The molecular weight standards are HaeIII-digested pUC18 (M1) and EcoRI/HindIII double-digested $\lambda$ DNA (M2).

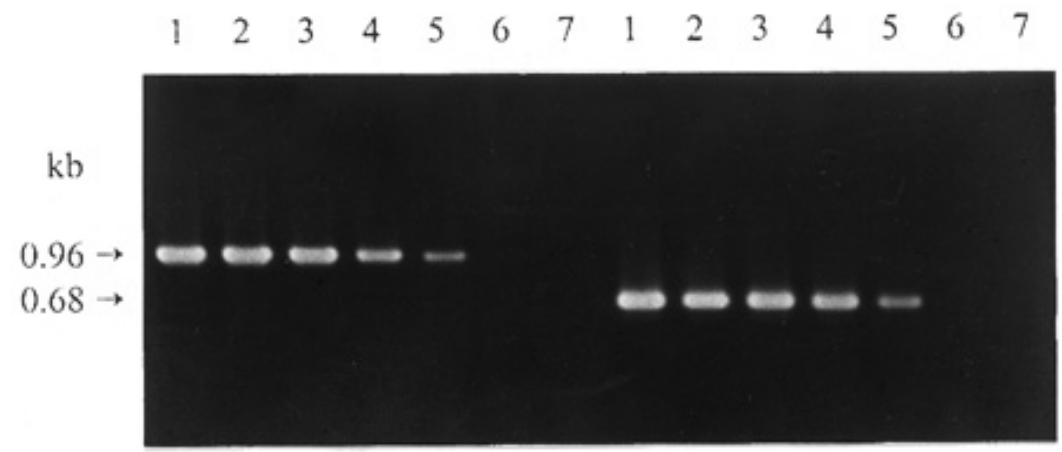

Fig. 5. Sensitivity of polymerase chain reaction (PCR) assay using Sporisorium reiliana-specific primer pairs SR1 (left) and SR3 (right). PCR amplification was performed from decreasing quantities of total S. reiliana DNA as templates: $1,000 \mathrm{pg}(1), 200 \mathrm{pg}(2), 40 \mathrm{pg}(3), 8 \mathrm{pg}$ (4), $1.6 \mathrm{pg}(5), 0.32 \mathrm{pg}$ (6), and $0.064 \mathrm{pg}$ (7). All reactions were spiked with $100 \mathrm{ng}$ of maize genomic DNA. PCR products were resolved by $1 \%$ agarose gel electrophoresis.
pSS11 and pSS34 of S. reiliana as well as pSU11 and pSU71 of $U$. maydis were selected for further analyses.

Sensitivity of probes in dot blot hybridization. Insert fragments of the above four subclones pSS11, pSS34, pSU11, and pSU71 were labeled with Dig-dUTP by PCR amplification and used as probes in dot blot hybridizations to determine their sensitivity in detection of fungal DNA. After $3 \mathrm{~h}$ exposure, strong hybridization signals were detected in dots with 100, 20, and $4 \mathrm{ng}$ of fungal DNA for each probe. The minimum amount of fungal DNA detected with this exposure time was $0.16 \mathrm{ng}$ (Fig. 3) and was even less than $0.032 \mathrm{ng}$ if the exposure time was extended to more than $15 \mathrm{~h}$.

Sequencing, primer design, and sensitivity of the PCR assay. Terminal regions (about 300 to 400 nucleotides) of insert fragments of four subclones were sequenced and compared with all sequence data available in the GenBank sequence database. No identical or nearly identical sequences were found. Abundant sequences of $S$. reiliana cloned in pSS11 and pSS34 were more AT-rich (63.1 to 68.9\%) than those of $U$. maydis in pSU11 and pSU71 (51.9 to $60.0 \%$ ).

Four primer pairs (SR1, SR3, UM1, and UM7) were designed corresponding to insert terminal sequences of pSS11, pSS34, pSU11, and pSU71 (Table 2). The primer pairs SR1 and SR3 specifically amplified genomic DNAs of all eight $S$. reiliana isolates, but not those of $U$. maydis, $F$. graminearum, $S$. turcica, or maize. Primer pair UM1 can amplify genomic DNAs of $14 U$. maydis isolates, resulting in different amplicons: isolates UI1, UI2, UI6, UI7, and UI10 showed one strong $0.94-\mathrm{kb}$ band, and the other nine isolates showed two faint bands of 0.94 and $1.80 \mathrm{~kb}$. No PCR product was obtained by using primer pair UM7.

A species-specific primer capable of producing the same amplicon for all $U$. maydis isolates was obtained by isolating one faint 0.94-kb PCR band and cloning it into plasmid $\mathrm{pBluescript.} \mathrm{Terminal} \mathrm{regions}$ of this band were sequenced and compared with those of pSU11. The conserved sequences were used to design a new primer pair UM11 (Table 2). After PCR amplification with this new primer pair, one strong 0.90-kb PCR band was observed in agarose gel electrophoresis for all $14 U$. maydis isolates (Fig. 4). As expected, this new primer pair cannot amplify genomic DNAs from any $S$. reiliana isolates, $F$. graminearum, S. turcica, or maize.

Sensitivity of the PCR assay was evaluated with each of primer pairs SR1, SR3, and UM11. PCR amplification was performed using variable amounts of fungal template DNA ranging from $1,000 \mathrm{pg}$ to $0.064 \mathrm{pg}$. In a parallel PCR assay, $100 \mathrm{ng}$ of maize genomic DNA was added to each PCR reaction. As a result, one sharp PCR 
band of the expected size was observed for each primer pair. The lowest amounts of detectable fungal DNA were $1.6 \mathrm{pg}$ for both $S$. reiliana-specific primer pairs SR1 and SR3, and $8 \mathrm{pg}$ for the $U$. maydis-specific primer UM11, irrespective of the presence of maize DNA (Figs. 5 and 6).

PCR-based detection of $S$. reiliana. DNA extracts of plant organs (leaf, node, pith, and shank) from both S. reilianainfected and -noninfected plants were subjected to PCR amplification using $S$. reiliana-specific primer pairs $\mathrm{SR} 1$ and SR3. Expected PCR products were obtained from DNA extracts of node, pith, and shank of infected plants, but not from leaves of infected plants nor from any organ of noninfected plants (Fig. 7).

\section{DISCUSSION}

Resistance of maize against the fungus $S$. reiliana is usually evaluated phenotypically for adult plants. A major drawback of this approach is that symptoms appear after flowering, limiting selection to the female parents. Moreover, in the case of affected ears, differentiation between symptoms caused by $S$. reiliana and $U$. maydis can be difficult. Hence, a method of early and specific identification of $S$. reiliana could improve the efficiency of resistance breeding, especially if combined with a method of artificial inoculation (14,28), allowing evaluation of materials independent of natural infection and season.

Chlorotic spots occurring on seedlings after infection with $S$. reiliana were proposed as an indicator of resistance in a seedling test (14). Unfortunately, expression of chlorotic spots depends on the genotype of the materials under investigation (6), and no absolute relationship was found between greenhouse and field tests, especially for hybrids (14). For our materials, including inbred lines highly susceptible or resistant to natural infection, no chlorotic spots were observed after artificial infection with $S$. reiliana, while the

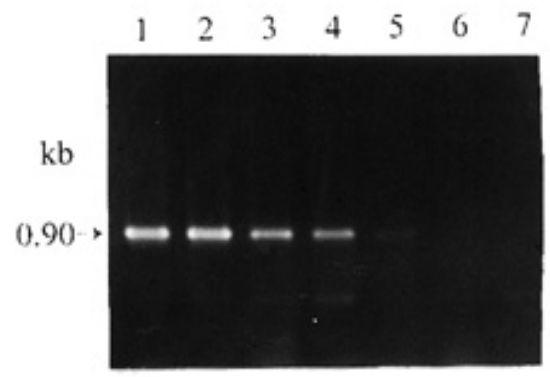

Fig. 6. Sensitivity of polymerase chain reaction (PCR) assay using Ustilago maydis-specific primer pair UM11. PCR amplification was performed from decreasing quantities of total $U$. maydis DNA as template: $1,000 \mathrm{pg}(1), 200$ pg (2), 40 pg (3), 8 pg (4), 1.6 pg (5), 0.32 pg (6), and $0.064 \mathrm{pg}(7)$. All reactions were spiked with $100 \mathrm{ng}$ of maize genomic DNA. PCR products were resolved by $1 \%$ agarose gel electrophoresis. fungus was detectable by our PCR assay (data not shown). Hence, usefulness of chlorotic spots as indicators for susceptibility-resistance might be limited to a fraction of the maize germ plasm.

An enzyme-linked immunosorbent assay (ELISA) has been developed for detection of various pathogens in plants $(20,27)$. ELISA was found to be sensitive and species-specific, although cross-reactions between related species can not be precluded $(18,20,27)$. However, the development of specific antibodies is laborious and still lacking for $S$. reiliana. Staining techniques based on reporter genes like $\beta$-glucuronidase (GUS) (23) and green fluorescent protein (GFP) (26) have been established for $U$. maydis. The technique was very powerful for studying hostpathogen interactions in vivo, but was not suitable for diagnosis of pathogens under natural conditions.

Recently, DNA-based diagnostic methods have been developed as highly sensitive and species-specific tools. Different types of abundant and single-copy sequences have been employed in hybridization or PCR-based techniques for pathogen detection. Abundant sequences, if speciesspecific, are most appropriate for diagnosis, because their detection is possible with high sensitivity. Within different types of abundant DNA sequences, repetitive genomic and unique mitochondrial DNA sequences were frequently reported to be species-specific. Directed cloning of such repetitive or mitochondrial sequences is laborious. However, shotgun cloning and screening with labeled total genomic DNA enables rapid identification of clones bearing abundant sequences with a high probability. The subsequent removal of clones containing nonspecific abundant DNA can be achieved by cross-hybridization. In the present study, cross-hybridization of labeled genomic DNA of $U$. maydis to $S$. reiliana clones and vice versa effi- ciently removed clones with nonspecific abundant DNA, since both pathogens are taxonomically related (9). In colony hybridization, $32 \mathrm{~S}$. reiliana colonies gave strong signals with labeled total DNA of $S$. reiliana; 21 of them gave no or only weak signals in cross-hybridization with the labeled total DNA of $U$. maydis. Likewise, analysis of $U$. maydis yielded 28 colonies containing abundant DNA, 20 with no or only weak cross-reactions with $U$. maydis. Subsequent dot blot and Southern hybridization detected four probes (pSS11, pSS34, pSU11, and pSU71) with high sensitivity and absolute or almost complete species specificity. Species specificity is required for the application of simple hybridization techniques for diagnosis such as dot blot or squash blot hybridization (17), in which the presence or absence of strong signals serves as criterion. Probe pSS34 can be directly used to identify $S$. reiliana isolates by dot blot hybridization, because of its absolute specificity to $S$. reiliana, while the other $S$. reiliana probe, pSS11, is not recommended for this application owing to its weak cross-reaction with $U$. maydis. Both $U$. maydis probes pSU11 and pSU71 showed weak cross-reactions with $S$. reiliana as well. They could be employed for detection of $U$. maydis only after using probe pSS34 to ensure that galls are not caused by $S$. reiliana.

The PCR assay developed here is more specific and sensitive than dot blot hybridization. Primers SR1 and SR3 each yielded a strong PCR band with all eight $S$. reiliana isolates tested and none with $U$. maydis or any other important fungal pathogen of maize. Primer UM11 specifically amplified DNA fragments for all 14 $U$. maydis isolates, regardless of the fact that primers SR1 and UM11 were designed based on cloned DNA showing weak cross reactions in hybridization experiments. The high specificity of the PCR assay might be due to the sensitivity of mismatches be-
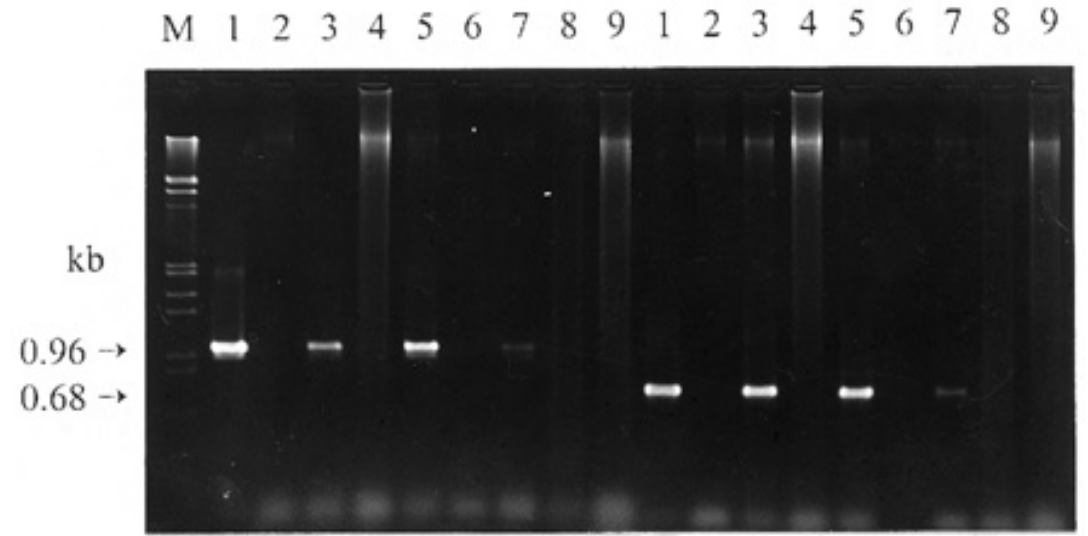

Fig. 7. Polymerase chain reaction (PCR) assay of Sporisorium reiliana with the two primer pairs SR1 (left: 1 to 9) and SR3 (right: 1 to 9). Template DNA was extracted from S. reiliana (1), shank of healthy plant (2), shank of infected plant (3), node of healthy plant (4), node of infected plant (5), pith of healthy plant (6), pith of infected plant (7), leaf of healthy plant (8), and leaf of infected plant (9). PCR products were resolved by $1 \%$ agarose gel electrophoresis. The molecular weight standard was EcoRI/HindIII double-digested $\lambda$ DNA (M). 
tween the short primer region and the target sequence. In contrast, base pairing in hybridization involves the complete DNA sequence of a probe and its target region and can tolerate a higher level of mismatches. Hence, in view of species specificity, the PCR-based assay is superior to dot blot hybridization. The same was true with regard to sensitivity, where the PCR assay detected less than $1.6 \mathrm{pg}$ of fungal DNA, making it 20 to 100 times more sensitive than dot blot hybridization.

In contrast to $U$. maydis, $S$. reiliana grows systemically in maize plants. For application of our $S$. reiliana probes or primers in resistance breeding, we addressed the question of whether $S$. reiliana can be detected in all parts of infected plants. S. reiliana-infected and -noninfected mature plants collected in a 1997 field trial were subdivided into leaves, node, pith, and shank. The PCR assay detected $S$. reiliana in all parts of the plant except in leaves. Comparable results were obtained with artificially inoculated seedlings of susceptible genotypes, where $S$. reiliana was detected in stems but not in leaves (G. Q. Tan, unpublished results). These findings are in agreement with the absence of chlorotic spots on leaves in our materials. Using more sensitive PCR-based methods such as nested PCR (16) or PCR combined with subsequent hybridization (25) might help to detect even lower amounts of $S$. reiliana. However, the risk of producing false positive signals by these methods is also elevated (16).

The PCR assay based on primer pair SR1 or SR3 developed here is a sensitive and species-specific tool for diagnosis of $S$. reiliana infection prior to flowering and could facilitate maize resistance breeding against $S$. reiliana. Since the PCR assay did not detect $S$. reiliana in leaves of infected plants, at least in our materials, a method using stems must to be employed, which is destructive to the plants evaluated. Therefore, the assessment of resistance against $S$. reiliana has to be based on progeny rather than on single plants. Nevertheless, depending on the germ plasm employed and the sensitivity of the detection method, a future application to single plants might be possible. Furthermore, $S$. reiliana primer pair SR1 or SR3, in combination with $U$. maydis primer pair UM11, allows a clear distinction between $S$. reiliana and $U$. maydis either by separate PCR assays or by a duplex PCR assay. For instance, this PCR procedure would greatly improve testing efficiency in distinction of teliospores of $S$. reiliana and $U$. maydis in seed lots for phytosanitary certi- fication. In addition, the PCR assay could be valuable for epidemiological and etiological studies, e.g., to monitor mycelium growth through the infected plant.

\section{ACKNOWLEDGMENTS}

We gratefully acknowledge Xianchun Xia and Guangqian Tan for excellent technical assistance and Günter Welz and Evelyn Möller for critically reading the manuscript and making helpful suggestions. We also thank Joerg Kaemper for supplying $U$. maydis isolates.

\section{LITERATURE CITED}

1. Ali, A., and Baggett, J. R. 1990. Inheritance of resistance to head smut disease in corn. J. Am. Soc. Hortic. Sci. 115:668-672.

2. Banuett, F. 1995. Genetics of Ustilago maydis, a fungal pathogen that induces tumors in maize. Annu. Rev. Genet. 29:179-208.

3. Bojanowski, J. 1969. Studies of inheritance of reaction to common smut in corn. Theor. Appl. Genet. 39:32-42.

4. De Boer, S. H., and Ward, L. J. 1995. PCR detection of Erwinia carotovora subsp. atroseptica associated with potato tissue. Phytopathology 85:854-858.

5. Dutzmann, S., and Duben, J. 1993. Maiskopfbrand zukünftig auch in Deutschland von Bedeutung? Mais 21:140-143.

6. Foster, J. H., and Frederiksen, R. A. 1997. Symptoms of head smut in maize seedlings and evaluation of hybrids and inbreds. Tex. Agric. Exp. Stn. Rep. PR3432.

7. Hoisington, D. A., Khairallah, M. M., and Gonzales-de-leon, D. 1994. Laboratory Protocols: CIMMYT Applied Molecular Genetics Laboratory, 2nd ed. CIMMYT, Mexico, DF.

8. Kreuzinger, N., Podeu, R., Gruber, F., Göbl, F., and Kubicek, C. P. 1996. Identification of some ectomycorrhizal basidiomycetes by PCR amplification of their gpd (glyceraldehyde-phosphate dehydrogenase) genes. Appl. Environ. Microbiol. 62:3432-3438.

9. Langdon, R. F. N., and Fullerton, R. A. 1978. The genus Sphacelotheca (Ustilaginales): Criteria for its delimitation and the consequences thereof. Mycotaxon 6:421-456.

10. Lee, I.-M., Davis, R. E., and Dewitt, W. D. 1990. Nonradioactive screening methods for isolation of disease-specific probes to diagnose plant disease caused by mycoplasmalike organisms. Appl. Environ. Microbiol. 56: 1471-1475.

11. Lee, I.-M., Gundersen, D. E., Hammond, R. W., and Davis, R. E. 1994. Use of mycoplasmalike organism (MLO) group-specific oligonucleotide primers for nested-PCR assays to detect mixed-MLO infections in a single host plant. Phytopathology 84:559-566.

12. Lee, I.-M., Hammond, R. W., Davis, R. E., and Gundersen, D. E. 1993. Universal amplification and analysis of pathogen $16 \mathrm{~S} \mathrm{rDNA}$ for classification and identification of mycoplasmalike organisms. Phytopathology 83: 834-842.

13. Li, K. N., Rouse, D. I., and German, T. L. 1994. PCR primers that allow intergeneric differentiation of Ascomycetes and their application to Verticillium spp. Appl. Environ. Microbiol. 60:4324-4331.

14. Matyac, C. A., and Kommedahl, T. 1985. Occurrence of chlorotic spots on corn seedlings infected with Sphacelotheca reiliana and their use in evaluation of head smut re- sistance. Plant Dis. 69:251-254.

15. Matyac, C. A., and Kommedahl, T. 1985. Factors affecting the development of head smut caused by Sphacelotheca reiliana on corn. Phytopathology 75:577-581.

16. McManus, P. S., and Jones, A. L. 1995. Detection of Erwinia amylovora by nested PCR and PCR-dot-blot and reverse-blot hybridizations. Phytopathology 85:618-623.

17. Mesbah, M., De Bock, T. S. M., Sandbrink, J. M., Klein-Lankhorst, R. M., and Lange, W. 1996. Selection of monosomic addition plants in offspring families using repetitive DNA probes in Beta L. Theor. Appl. Genet. 92:891897.

18. Opgenorth, D. C., Smart, C. D., Louws, F. J., de Bruijn, F. J., and Kirkpatrick, B. C. 1996. Identification of Xanthomonas fragariae field isolates by rep-PCR genomic fingerprinting. Plant Dis. 80:868-873.

19. Owens, R. A., and Diener, T. O. 1981. Sensitive and rapid diagnosis of potato spindle tuber viroid disease by nucleic acid hybridization. Science 213:670-671.

20. Plasencia, J., Jemmerson, R., and Banttari, E. E. 1996. Production and characterization of monoclonal antibodies to Verticillium dahliae and development of a quantitative immunoassay for fungal biomass. Phytopathology 86:170-176.

21. Pooler, M. R., Pitchie, D. F., and Hartung, J. S. 1996. Genetic relationship among strains of Xanthomonas fragariae based on random amplified polymorphic DNA PCR, repetitive extragenic palindromic PCR, and Enterobacterial repetitive intergenic consensus PCR data and generation of multiplexed PCR primers useful for the identification of this phytopathogen. Appl. Environ. Microbiol. 62:3121-3127.

22. Puhalla, B. J. 1970. Genetic studies of the b incompatibility locus of Ustilago maydis. Genet. Res. Camb. 16:229-232.

23. Richard, G., Bailey, J. A., Keon, J. P. R., and Hargreaves, J. R. 1992. Development of a GUS reporter gene system for the maize pathogen Ustilago maydis. Physiol. Mol. Plant Pathol. 40:383-393.

24. Sambrook, J., Fritsch, E. F., and Maniatis, T. 1989. Molecular Cloning: A Laboratory Manual. 2nd ed. Cold Spring Harbor Laboratory, Cold Spring Harbor, NY.

25. Schilling, A. G., Möller, E. M., and Geiger, H. H. 1996. Polymerase chain reaction-based assays for species-specific detection of Fusarium culmorum, F. graminearum, and $F$. avenaceum. Phytopathology 86:515-522.

26. Spellig, T., Bottin, A., and Kahmann, R. 1996. Green fluorescent protein (GFP) as a new vital marker in the phytopathogenic fungus Ustilago maydis. Mol. Gen. Genet. 252:503509.

27. Sutula, C. L., Gillett, J. M., Morrissey, S. M., and Ramsdell, D. C. 1986. Interpreting ELISA data and establishing the positivenegative threshold. Plant Dis. 70:722-726.

28. Whythe, I. V., and Gevers, H. O. 1988. Diallel analysis of resistance of eight maize inbred lines to Sphacelotheca reiliana. Phytopathology 78:65-68.

29. Yao, C. L., Magill, C. W., and Frederiksen, R. A. 1991. Use of an A-T-rich DNA clone for identification and detection of Peronosclerospora sorghi. Appl. Environ. Microbiol. 57:2027-2032. 